\title{
An evaluation system for urban growth
}

\author{
Wenjie Zheng \\ Power University Baoding, Baoding 071000, China \\ 2893687936@qq.com
}

\begin{abstract}
The paper focuses on establishing an effective evaluation system for smart urban growth plans. The system is subdivided into three subsystems which are Economically prosperous, socially Equitable, and Environmentally Sustainable. The paper sets up eleven indicators to reflect the subsystems. We make research on the restriction and coordination between them to figure out the weights of each indicators. Based on it, we finally give an evaluation system with five levels for the urban growth plans.
\end{abstract}

Keywords: Evaluation System, Urban Growth, Economically Prosperous, Socially Equitable, Environmentally Sustainable

\section{INTRODUCTION}

The world has continued to urbanize since 1950s, and now world urbanization still tend to be rapid. Globally, more people live in urban areas than in rural areas, with 54 per cent of the world's population residing in urban areas in 2014. In 1950, 30 per cent of the world's population was urban, and by 2050, 66 per cent of the world's population is projected to be urban [1].

However, urban land area is far smaller than the rural. It is a great challenge for the urban to support more people with less land. Hence, urban planning has become increasingly important and necessary to ensure that people have access to equitable and sustainable homes, resources and jobs.

To develop sustainably, many communities are implementing smart growth initiatives. "Its original purpose is to establish a mean to enable the state government to guide the development of the city, and ensure that the government expenditure on urban development has a positive impact on cities' growth,” Maryland governor Glenn Denning pointed out in 1997. In general, it is aimed at focuses on building cities that embrace the E's of sustainability-Economically prosperous, socially Equitable, and Environmentally Sustainable. More specifically, smart growth need to meet its ten principles.

To implementing smart growth theories into city design around the world, the paper proposes reasonable metric to measure the success of smart growth of a city.

\section{THE EVALUATION MODEL}

\subsection{The Complexity of The Evaluation System}

We firstly ensure that the evaluation system of smart growth is complex. Although society, economy and environment are three different properties of the system, each of which has their own structures, functions and development rules, their respective existence and development are restricted by the structure and function of other systems. Obviously, this problem cannot be regarded as a simple social, economic or natural problem, but a complex problem related to several systems. In order to evaluate the smart growth of a city precisely, we set up a society, economy and environment complex evaluation system.

It is a multidimensional decision-making process to study on the composite evaluation system, we need to evaluate comprehensively, plan and coordinate the organization, correlation, orderliness of the system. The goal set is measured by three sub combined index system, which namely are Economically prosperous, socially Equitable, and Environmentally Sustainable. We finally conclude that the index of composite evaluation system is specific social goals, economic goals and ecological goals, make the highest comprehensive benefit the most development opportunities for community. 


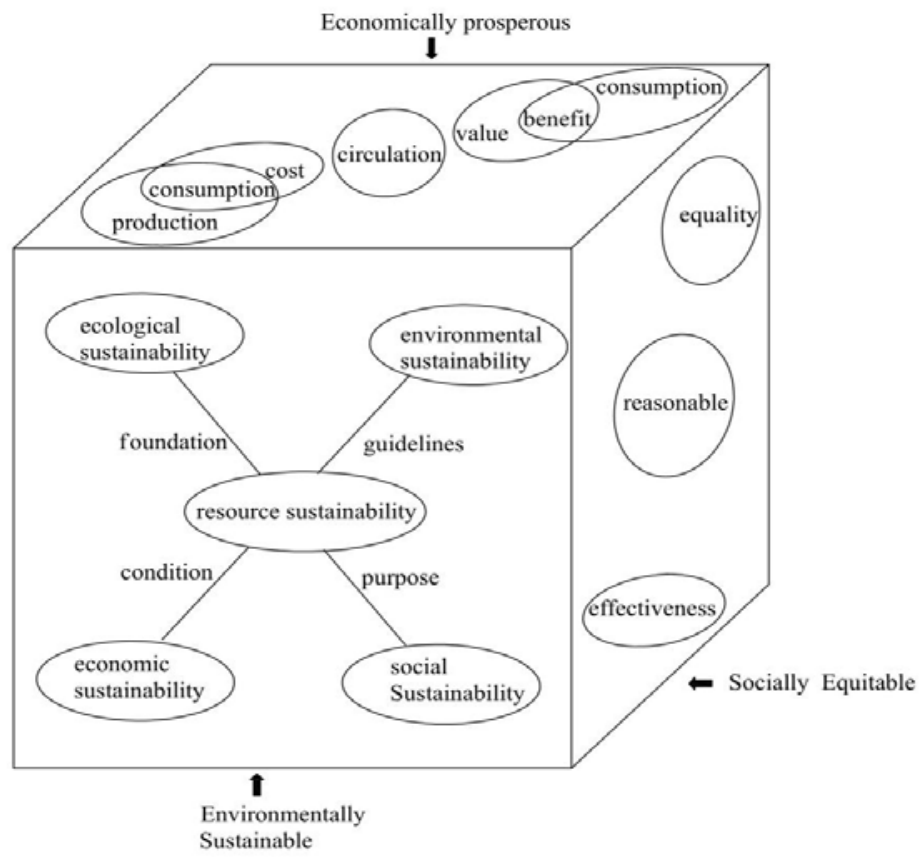

FIGURE 1. City society-economy-nature composite system

\subsection{Obtain the Evaluation Norm}

The paper firstly develops a composite evaluation system, which takes economic prosperity, social justice, environmental sustainable as three variables. Then, taking into account the impact of the three variables on the smart growth plan, it figures out the value of $\mathrm{W}$ and draw conclusions whether the smart growth plan is successful.

In figure 2, $\mathrm{A}, \mathrm{B}, \mathrm{C}$ represent the city's social benefits, economic benefits and environmental benefits. There are there points: $\mathrm{P}_{0}\left(\mathrm{x}_{0}, \mathrm{y}_{0}, \mathrm{z}_{0}\right), \mathrm{P}_{1}\left(\mathrm{x}_{1}, \mathrm{y}_{1}, \mathrm{z}_{1}\right), \mathrm{P}_{2}\left(\mathrm{x}_{2}, \mathrm{y}_{2}, \mathrm{z}_{2}\right)$. It is known that the result of $\mathrm{x}_{0}+\mathrm{y}_{0}+\mathrm{z}_{0}$ is larger than $\mathrm{x}_{1}$ $+\mathrm{y}_{1}+\mathrm{z}_{1}$, and the result of $\mathrm{x}_{1}+\mathrm{y}_{1}+\mathrm{z}_{1}$ is smaller than $\mathrm{x}_{2}+\mathrm{y}_{2}+\mathrm{z}_{2}[2]$.

If we take the calculation method of conjunction as a standard, it will be concluded that the comprehensive benefit value of P0 is larger than P2. However, From the point of view of smart growth, we should draw a totally opposite conclusion. Consequently, in the rational estimation of the comprehensive effect of smart growth in communities, it is inappropriate to assess the comprehensive effect by adding the scores of each subsystem of the evaluation system.

More precisely, the mathematical evaluation model of the smart growth index system should be based on the theory of balanced and coordinated development, which can be used to both evaluate the urban construction based on smart growth and guide its comprehensive development.

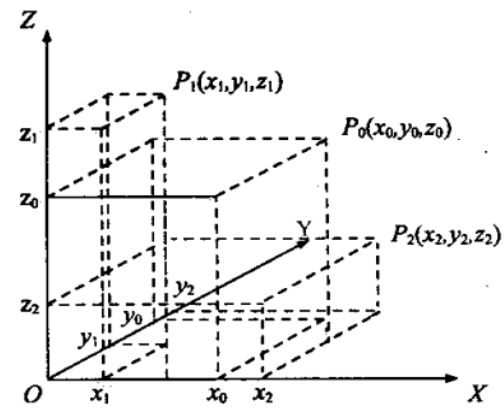

FIGURE 2. Model structure of urban complex evaluation system

In a community, not only the function and development principles of its three subsystems are different, but also their existence and development are controlled by other system's structure and function. Therefore, the interaction 
and restriction between these three sub systems should be taken into consideration when making city plans. But under the present conditions of all cities, it is impossible to achieve unlimited development of social benefits, economic benefits and environment benefit. What we can do is to pursue coordinated and balanced development under the existing conditions, and to make the combined big city system achieve the maximum benefits.

Suppose see the social, economic, environmental benefits A, B, C as variables, the present certain conditions can be described in the function:

$$
\mathrm{f}(\mathrm{A}, \mathrm{B}, \mathrm{C})=0
$$

City planning based on smart growth is in most the pursuit of social, economic and environmental benefits under the existing conditions. Since the three have reached the ideal value, the most successful situation of smart growth should be the pursuit of maximizing the value of $\mathrm{W}$.

$$
\mathrm{W}=\mathrm{A} * \mathrm{~B} * \mathrm{C}
$$

\subsection{Specify the Evaluation System}

According to the ten principles of urban intelligent growth and the three E's of sustainability, we choose some representative indicators from the natural, social and economic systems of the city and establish the following threeindex-system sheet, and then do some relevant calculation to get the value of A, B and C.

\begin{tabular}{|c|c|c|c|c|c|c|c|}
\hline $\begin{array}{l}\text { The first } \\
\text { order index }\end{array}$ & $\begin{array}{l}\text { The second } \\
\text { level index }\end{array}$ & $\begin{array}{l}\text { The third } \\
\text { level index }\end{array}$ & $\begin{array}{c}\text { Present } \\
\text { value }\end{array}$ & $\begin{array}{c}\text { Standard } \\
\text { value }\end{array}$ & Indicator & Property & Proportion \\
\hline & & $\begin{array}{l}\text { land use } \\
\text { efficiency }\end{array}$ & $a_{1}$ & $a_{10}$ & $A_{1}$ & promote & $P_{I}$ \\
\hline & Fnyironmentally & $\begin{array}{c}\text { urban greening } \\
\text { rate }\end{array}$ & $a_{2}$ & $a_{20}$ & $\mathrm{~A}_{2}$ & promote & $P_{2}$ \\
\hline & & air pollution index & $a_{3}$ & $a_{30}$ & $\mathrm{~A}_{3}$ & restrain & $P_{3}$ \\
\hline & & $\begin{array}{l}\text { noise grade of } \\
\text { environment }\end{array}$ & $a_{4}$ & $a_{40}$ & $\mathrm{~A}_{4}$ & restrain & $P_{4}$ \\
\hline & & $\begin{array}{l}\text { natural population } \\
\text { growth rate }\end{array}$ & $b_{1}$ & $b_{10}$ & $B_{1}$ & promote & $Q_{l}$ \\
\hline \multirow{6}{*}{$\begin{array}{l}\text { Urban } \\
\text { Intelligent } \\
\text { Growth } \\
\text { Rate }\end{array}$} & $\begin{array}{l}\text { Socially } \\
\text { Equitable }\end{array}$ & $\begin{array}{c}\text { residential area } \\
\text { per capita }\end{array}$ & $b_{2}$ & $b_{20}$ & $B_{2}$ & promote & $Q_{2}$ \\
\hline & & $\begin{array}{c}\text { policy decision } \\
\text { participation }\end{array}$ & $b_{3}$ & $b_{30}$ & $B_{3}$ & promote & $Q_{3}$ \\
\hline & \multirow{4}{*}{$\begin{array}{l}\text { Economically } \\
\text { Prosperous }\end{array}$} & $\begin{array}{l}\text { GDP level } \\
\text { per capita }\end{array}$ & $c_{1}$ & $c_{10}$ & $C_{1}$ & promote & $R_{I}$ \\
\hline & & $\begin{array}{l}\text { popularization } \\
\text { of transportation }\end{array}$ & $c_{2}$ & $c_{20}$ & $C_{2}$ & promote & $R_{2}$ \\
\hline & & $\begin{array}{c}\text { scientific and } \\
\text { technological } \\
\text { development level }\end{array}$ & $c_{3}$ & $c_{30}$ & $C_{3}$ & promote & $R_{3}$ \\
\hline & & $\begin{array}{l}\text { community } \\
\text { economic } \\
\text { development }\end{array}$ & $c_{4}$ & $c_{40}$ & $C_{4}$ & promote & $R_{4}$ \\
\hline
\end{tabular}

TABLE 1. Index system of evaluation system

The principles of selecting the standard value of each index are:

1) When there's a national or international standard indicator, using the standard value.

2) Refer to the relevant cities in the study of the best indicators, take it as the standard value of the indicator. 
- Obtain of the third level indexes $A_{i}, B_{i}$ and $C_{i}$

If the index means the level of urban intelligence level is not good enough,

$$
\begin{aligned}
& A_{i}=1-\frac{\left|a_{i 0}-a_{i}\right|}{a_{i 0}} \\
& B_{i}=1-\frac{\left|b_{i 0}-b_{i}\right|}{b_{i 0}} \\
& C_{i}=1-\frac{\left|C_{i 0}-C_{i}\right|}{C_{i 0}}
\end{aligned}
$$

- If the index means the level of urban intelligence level has reached the developed level,

$$
\begin{aligned}
& A_{i}=1 \\
& B_{i}=1 \\
& C_{i}=1
\end{aligned}
$$

As to the proportions of the indicators, we would conduct a specific analysis according to different cities. In general, in order not to be influenced by subjective judgment, the proportion of each indicator is assigned according to the arithmetic average weighted method. It should be noted that the use of this method is not the ultimate goal, but only the indicators of the merger, and thus facilitate the results for further analysis.

- Obtain the second level indexes A, B and C

$$
\begin{aligned}
& \mathrm{A}=\sum_{i=1}^{4} A_{i} \cdot P_{i} \\
& \mathrm{~B}=\sum_{i=1}^{4} B_{i} \cdot Q_{i} \\
& \mathrm{C}=\sum_{i=1}^{4} C_{i} \cdot R_{i}
\end{aligned}
$$

The first-level indicator $\mathrm{W}$ reflects the intelligent level of the city. We can get the value of the first order index W according to formula (2).

\section{Conclusions}

Referring to the foreign comprehensive indexes’ grouping method and Yongchang Song's urban ecological level of 5 levels of classification standards, I designed a evaluation system with five levels and give the corresponding rating in Table 2.

TABLE 2. Classification of urban smart growth

\begin{tabular}{ccc}
\hline Level & $W$ & Comment \\
\hline I & $>0.75$ & Hightly successful \\
II & $0.5-0.75$ & Successful \\
III & $0.35-0.5$ & Common \\
IV & $0.25-0.35$ & Less successful \\
V & $<0.25$ & Unsuccessful \\
\hline
\end{tabular}

In the establishment of index system of ecology city, the city ecological system is a complex system including many factors. Ecological evaluation of it may not be exhaustive and can only choose several factors of all as the evaluation indexes. Moreover, index selection principle should pay attention to comprehensiveness, representation, hierarchy, rationality and reality [3]. According to this principle, he set up an ecological city index system with four levels. What's more, for the core indicators' standard values of the index system, he thought it over carefully, and list 5 principles to solve this problem. Then, he finally established the reasonable standard of the selected index value and calculated the city comprehensive ecological value index using the weighted factor comprehensive method to evaluate the analysis of ecological level of a city. This is very similar to the smart growth evaluation system from both principles and methods, so we adopt most of its grading standards when established smart growth evaluation system.

\section{REFERENCES}

1. https://esa.un.org/unpd/wup/Publications/Files/WUP2014-Highlights.pdf

2. Xingping Zhu. Establishment of mathematical model of Ecological City[J]. Sichuan Environment, 2004,(02):59-63. 
3. Yongchang Song. Index system and evaluation method of ecology city[J]. Urban environment and urban ecology,1999,(05):16-19. 